ISSN 0258-7122

Bangladesh J. Agril. Res. 36(4): 669-676, December 2011

\title{
INTERCROPPING LENTIL WITH MUKHIKACHU (Collocasia esculenta) AT DIFFERENT PLANTING SYSTEMS
}

\author{
M. S. $\operatorname{ALOM}^{1}$, M. N. ISLAM ${ }^{2}$, B. L. NAG ${ }^{3}$ \\ M.M. HOWLADER ${ }^{4}$ AND M. A. HOSSAIN ${ }^{5}$
}

\begin{abstract}
The experiment was conducted at the Regional Agricultural Research Station, BARI, Jessore during consecutive two years (2007-08 and 2008-09) to find out the comparative performance of different intercropped lentil with Mukhikachu for getting higher yield and economic return. Five treatments comprised of $\mathrm{T}_{1}=$ Sole lentil (30 $\mathrm{cm}$ apart continuous seeding), $\mathrm{T}_{2}=$ Sole mukhikachu [(double row) $=20 \mathrm{~cm} / 55 / 20 \mathrm{~cm} \times 45 \mathrm{~cm}], \mathrm{T}_{3}=$ Mukhikachu (double row) +1 row of lentil $30 \mathrm{~cm}$ apart (33\% seeding ratio) between 2 double row of mukhikachu, $\mathrm{T}_{4}$ $=$ Mukhikachu (double row) +2 rows of lentil $30 \mathrm{~cm}$ apart $(66 \%)$ between 2 double row of mukhikachu and $\mathrm{T}_{5}=$ Mukhikachu (double row) + lentil broadcast $(100 \%)$. Intercropping systems did not affect the rhizome yield of mukhikachu significantly but affected the seed yield of lentil. Lentil and mukhikachu equivalent yield were the highest (5.87 in 2007-08 and 6.09 t/ha in 2008-09, and 27.24 in 2007-08 and 30.45 t/ha in 2008-09, respectively) in treatment $\mathrm{T}_{4}$. This treatment also gave the highest LER (1.63 in 2007-08 and 1.54 in 2008-09), net return (Tk. 290508 in 2007-08 and Tk. 368900/ha in 2008-09) with BCR of 4.19 in 2007-08 and 4.88 in 2008-09, respectively. It reveals that lentil could be grown easily in double row system of Mukhikachu without hampering yield of Mukhikachu with higher benefit and also enhanced lentil production in the area.
\end{abstract}

Keywords: Intercropping lentil with Mukhikachu, planting system.

\section{Introduction}

Mukhikachu, a carbohydrate and protein rich tuber vegetable crop, which is generally grown during February/March to September/October (Salam et al., 2003). But farmers of Kustia, Pabna, and Jessore usually grow Mukhikachu in some areas in the last week of October to mid November in order to make it available in the market during the month of July/ August, when market price is high. During winter season, the growth of Mukhikachu is slow due to low temperature and after winter, the crop resumes its growth. During this period, farmers can easily grow lentil crop in association with Mukhikachu for higher benefit. Moreover, lentil is a leguminous crop which can fix atmospheric nitrogen into the soil. Relay cropping Mukhikachu with hybrid maize have been

\footnotetext{
${ }^{1}$ Senior Scientific Officer, Agronomy Division, Bangladesh Agricultural Research Institute (BARI), Gazipur, ${ }^{2}$ Principal Scientific Officer, Agronomy Division, BARI, Gazipur, ${ }^{3}$ Senior Scientific Officer, Agronomy Division, Regional Agricultural Research Station, BARI, Jessore, ${ }^{4}$ Scientific Officer, Spices Research Center, BARI, Faridpur, ${ }^{5}$ Chief Scientific Officer, Agronomy Division, BARI, Gazipur, Bangladesh.
} 
practicing by some farmers of Kustia district (Islam and Akhteruzzaman, 2008). However, literature regarding lentil-mukhikachu intercropping is not available. Hence, this experiment was conducted to find out the comparative performance of different seeding ratio of lentil intercropped with Mukhikachu for getting maximum benefit having minimum crop competition.

\section{Material and Method}

The experiment was carried out under rainfed condition at the Regional Agricultural Research Station, BARI, Jessore during two consecutive years November 2007 to August 2008 and November 2008 to August 2009 to find out the comparative performance of different intercropped lentil with Mukhikachu. The soil type of the experimental plot was sandy loam under AEZ 11. The total rainfall during crop period was $1050.08 \mathrm{~mm}$ in 2007-08 and $844.90 \mathrm{~mm}$ in 2008-09, respectively. Five treatments were tested in randomized complete block design with three replications. Treatments comprised $\mathrm{T}_{1}=$ Sole lentil $\left(30 \mathrm{~cm}\right.$ apart continuous seeding), $\mathrm{T}_{2}=$ Sole Mukhikachu [(double row) $=20 \mathrm{~cm} / 55 / 20 \mathrm{~cm} \mathrm{x} 45 \mathrm{~cm}], T_{3}=$ Mukhikachu (double row) +1 row of lentil $30 \mathrm{~cm}$ apart (33\% seeding ratio) between 2 double row of Mukhikachu, $\mathrm{T}_{4}=$ Mukhikachu (double row) +2 rows of lentil $30 \mathrm{~cm}$ apart $(66 \%)$ between 2 double row of Mukhikachu and $\mathrm{T}_{5}=$ Mukhikachu (double row) + lentil broadcast (100\%). The Mukhikachu variety BARI Mukhikachu 1 (Bilasi) and lentil variety BARI Masur 5 were used as the test crops. Seed rate of lentil and Mukhikachu were used 35 and $600 \mathrm{~kg} / \mathrm{ha}$, respectively. The unit plot size was $3.0 \mathrm{~m}$ $\mathrm{x} 4.5 \mathrm{~m}$. Sowing was done on 10 November 2007 and 15 November 2008, respectively. Fertilizers (BARC, 2005) were applied 15-18-15 N, P, and K kg/ha in the form of urea, triple super phosphate, and muriate of potash for lentil sole at the time of final land preparation. On the other hand, fertilizers (BARC, 2005) used for sole Mukhikachu and intercrop were 112-32-95-20 kg/ha NPKS, respectively. Except urea, all other fertilizers were applied during final land preparation. Urea was applied in two equal splits at 45 and 100 days after emergence of Mukhikachu in rows only. Plant protection measure and all other management practices were done as and when necessary. After harvest of lentil, supplementary irrigation was applied. Lentil was harvested on 12 and 15 March 2008 and 2009, whereas Mukhikachu on 10 and 16 August 2008 and 2009, respectively. Ten plants of lentil and Mukhikachu were selected randomly per plot to collect data on their yield attributes. Yield data was taken as whole plot basis which was expressed in t/ha, Yield of individual crop was converted into equivalent yield on the basis of the prevailing market price of respective crop (Bandyopadhyay, 1984). Relative yield was measured according to Jukinen (1991) and land equivalent ration (LER) was

also calculated as per Mead and Willey (1980). Gross return, total cost of cultivation, net return and benefit cost ratio (BCR) of different treatments were computed on the basis of prevailing market price of lentil and Mukhikachu. All necessary data were collected and analyzed by using MSTAT-C program. Means were separated by LSD $(p \leq 0.05)$ test. 


\section{Results and Discussion}

\section{Performance of lentil}

Significant variations were found with respect to plant population, number of pods/plant, seed yield in both the years and 1000-seed weight in only 2007-08 (Table 1). The highest plant population was obtained in broadcast system in both the years. Number of pods/plants was higher in treatment $T_{1}$, but statistically at par with treatment $T_{3}$ and $T_{4}$. Similar trend was followed in case of seed weight. The maximum seed yield (1.71 in 2007-08 and $1.94 \mathrm{t} / \mathrm{ha}$ in 2008-09) was obtained from sole lentil, which was statistically identical to $\mathrm{T}_{3}$ and $\mathrm{T}_{4}$ treatments and the lowest seed yield (0.68 in 2007-08 and $0.83 \mathrm{t} / \mathrm{ha}$ in 2008-09) was from $\mathrm{T}_{3}$ due to less plants $/ \mathrm{m}^{2}$. In all respect, plants $/ \mathrm{m}^{2}$ of lentil were less in 2008-2009 due to partially affected by foot rot disease, but it was compensated by higher number of pods/plant and 1000-seed weight. Sole lentil $\left(T_{1}\right)$ showed higher number of pods, 1000-seed weight, and seed yield in both the years mainly due to proper utilization of growth and developmental resources and there was no competition among intercrops. These findings are in agreement with the results of Kumar and Singh (1987). There was trend to increase seed yield with the increased number of rows of lentil but broadcast lentil (100\%) showed higher yield than 1 or 2 rows of lentil.

Table 1. Seed yield and yield components of lentil in Mukhikachu + lentil intercropping systems during 2007-08- and 2008-09.

\begin{tabular}{|c|c|c|c|c|c|c|c|c|c|c|}
\hline \multirow[t]{2}{*}{ Treatments } & \multicolumn{2}{|c|}{$\begin{array}{l}\text { Number of } \\
\text { plants } / \mathrm{m}\end{array}$} & \multicolumn{2}{|c|}{$\begin{array}{l}\text { Number of } \\
\text { pods/plant }\end{array}$} & \multicolumn{2}{|c|}{$\begin{array}{l}\text { Number of } \\
\text { seeds/pod }\end{array}$} & \multicolumn{2}{|c|}{$\begin{array}{c}\text { Weight of } \\
1000 \text {-seed } \\
(\mathrm{g})\end{array}$} & \multicolumn{2}{|c|}{$\begin{array}{l}\text { Seed yield } \\
\quad(\mathrm{t} / \mathrm{ha})\end{array}$} \\
\hline & 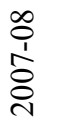 & $\begin{array}{l}\text { oे } \\
\text { के } \\
\text { ᄋे }\end{array}$ & 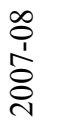 & $\begin{array}{l}\text { oे } \\
\text { के } \\
\text { ᄋे }\end{array}$ & 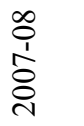 & $\begin{array}{l}\text { oे } \\
\text { 1 } \\
\text { oे } \\
\text { ì }\end{array}$ & 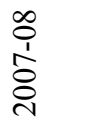 & $\begin{array}{l}\text { Oे } \\
\text { के } \\
\text { ᄋे }\end{array}$ & 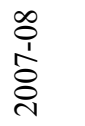 & $\begin{array}{l}\text { Oे } \\
\text { के } \\
\text { ᄋे }\end{array}$ \\
\hline $\mathrm{T}_{1}$ & 124 & 105 & 147 & 186 & 1.83 & 1.72 & 19.00 & 20.30 & 1.71 & 1.94 \\
\hline $\mathrm{T}_{3}$ & 72 & 67 & 140 & 185 & 1.80 & 1.94 & 18.87 & 22.60 & 0.68 & 0.73 \\
\hline $\mathrm{T}_{4}$ & 116 & 90 & 132 & 181 & 1.73 & 1.75 & 17.53 & 21.60 & 1.22 & 1.39 \\
\hline $\mathrm{T}_{5}$ & 152 & 127 & 108 & 145 & 1.70 & 1.65 & 15.67 & 19.50 & 1.40 & 1.62 \\
\hline $\operatorname{LSD}_{(p \leq 0.05)}$ & 29.42 & 22.24 & 21.89 & 15.94 & NS & NS & 2.14 & NS & 0.52 & 0.65 \\
\hline CV (\%) & 12.68 & 12.18 & 8.32 & 4.70 & 6.60 & 5.64 & 6.53 & 7.66 & 8.58 & 12.63 \\
\hline
\end{tabular}

$\mathrm{T}_{1}=$ sole lentil (30 $\mathrm{cm}$ apart continuos seeding),

$\mathrm{T}_{3}=$ Mukhikachu (double row) +1 row of lentil (33\% seeding ration) between 2 double row of Mukhikachu)

$\mathrm{T}_{4}=$ Mukhikachu (double row) +2 rows of lentil $(66 \%)$ between 2 double row of Mukhikachu and

$\mathrm{T}_{5}=$ Mukhikachu (double row) + lentil broadcast (100\%). 


\section{Performance of Mukhikachu}

Rhizome yield and yield attributes of Mukhikachu for both the years have been presented in Table 2. The results revealed that the sole and intercropping competition did not affect the growth, yield components, and yield of Mukhikachu. Though sole Mukhikachu showed higher yield and yield attributes, but close to each other with intercropping treatments. It was found that lentil did not hamper the normal growth of Mukhikachu. In comparing year, 2008-09 showed higher rhizome yield than 2007-08 due to higher yield attributes and less rainfall which might helped in proper growth.

Table 2. Rhizome yield and yield components of mukhikachu in Mukhikachu + lentil intercropping systems during 2007-08-and 2008-09

\begin{tabular}{|c|c|c|c|c|c|c|c|c|c|c|c|c|}
\hline \multirow[t]{2}{*}{$\begin{array}{c}\text { Treatme } \\
\text { nts }\end{array}$} & \multicolumn{2}{|c|}{$\begin{array}{c}\text { Wt of } \\
\text { primary corm } \\
(\mathrm{g})\end{array}$} & \multicolumn{2}{|c|}{$\begin{array}{l}\text { No. of } \\
\text { secondary } \\
\text { corms/ } \\
\text { plant }\end{array}$} & \multicolumn{2}{|c|}{$\begin{array}{l}\text { Wt of } \\
\text { secondary } \\
\text { corms/ } \\
\text { Plant (g) }\end{array}$} & \multicolumn{2}{|c|}{$\begin{array}{l}\text { No. of } \\
\text { cormels/ } \\
\text { plant }\end{array}$} & \multicolumn{2}{|c|}{$\begin{array}{l}\text { Wt of } \\
\text { cormels/ } \\
\text { plant }(\mathrm{g})\end{array}$} & \multicolumn{2}{|c|}{$\begin{array}{l}\text { Rhizome } \\
\text { yield } \\
\text { (t/ha) }\end{array}$} \\
\hline & 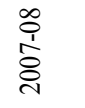 & $\begin{array}{l}\text { Oे } \\
\text { ò } \\
\text { ᄋे }\end{array}$ & 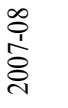 & $\begin{array}{l}\text { oे } \\
\text { ò } \\
\text { Oे }\end{array}$ & 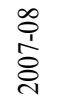 & $\begin{array}{l}\text { oे } \\
\text { ò } \\
\text { ᄋे }\end{array}$ & 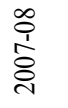 & $\begin{array}{l}\text { Oे } \\
\text { ò } \\
\text { ᄋे }\end{array}$ & 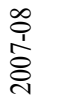 & $\begin{array}{l}\text { Oे } \\
\text { ò } \\
\text { ᄋे }\end{array}$ & 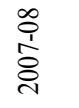 & $\begin{array}{l}\text { Oे } \\
\text { do } \\
\text { ᄋे } \\
\text { d }\end{array}$ \\
\hline $\mathrm{T}_{2}$ & 275 & 320 & 26.0 & 36.2 & 556.0 & 683.0 & 3.5 & 6.0 & 170.0 & 180.0 & 23.40 & 28.60 \\
\hline $\mathrm{T}_{3}$ & 235 & 323 & 24.5 & 32.0 & 538.3 & 692.0 & 3.4 & 5.5 & 150.0 & 162.0 & 22.00 & 25.70 \\
\hline $\mathrm{T}_{4}$ & 220 & 323 & 23.5 & 23.8 & 500.0 & 658.0 & 3.1 & 5.4 & 140.0 & 150.0 & 21.60 & 23.50 \\
\hline $\mathrm{T}_{5}$ & 200 & 267 & 22.4 & 29.0 & 468.3 & 639.0 & 3.0 & 5.3 & 132.0 & 133.0 & 18.60 & 20.00 \\
\hline LSD & NS & NS & NS & NS & NS & NS & NS & NS & NS & NS & NS & NS \\
\hline CV (\%) & 16.05 & 11.88 & 8.08 & 22.86 & 8.00 & 4.10 & 9.57 & 11.47 & 14.69 & 10.52 & 8.99 & 12.69 \\
\hline
\end{tabular}

$\mathrm{T}_{2}=$ Sole Mukhikachu [(double row $\left.)=20 \mathrm{~cm} / 55 / 20 \mathrm{~cm} \times 45 \mathrm{~cm}\right]$,

$\mathrm{T}_{3}=$ Mukhikachu (double row) +1 row of lentil (33\% seeding ratio) between 2 double row of Mukhikachu,

$\mathrm{T}_{4}=$ Mukhikachu (double row) +2 rows of lentil $(66 \%)$ between 2 double row of Mukhikachu and

$\mathrm{T}_{5}=$ Mukhikachu (double row) + lentil broadcast (100\%).

\section{Lentil and Mukhikachu equivalent yield}

The equivalent yield of lentil and Mukhikachu was significantly influenced by different intercropping systems (Table 3). Higher lentil equivalent yield (5.87 $\mathrm{t} / \mathrm{ha}$ in 2007-08 and 6.09 $\mathrm{t} / \mathrm{ha}$ in 2008-09) was recorded in $\mathrm{T}_{4}$, which was statistically identical to those of $\mathrm{T}_{2}, \mathrm{~T}_{3}$ and $\mathrm{T}_{5}$. Similar trend was found in case of Mukhikachu equivalent yield (27.24 t/ha in 2007-08 and 30.45 t/ha in 2008-09). It was noted that all the sole and intercropping systems gave higher lentil and Mukhikachu equivalent yields than that of their corresponding sole crop yields. The results indicated that $\mathrm{T}_{4}$ [Mukhikachu (double row +2 rows of lentil $(66 \%)$ 
between 2 double rows of Mukhikachu] was found to produce higher yield advantages of $243 \%$ in $2007-08$ and $214 \%$ in $2008-09$, and $16.41 \%$ in $2007-08$ and $6.47 \%$ in $2008-09$ over the corresponding sole crops of lentil and Mukhikachu, respectively. Similar observations in different intercropping systems were also made by other authors (Patra et al., 2000; Islam et al., 2006 and Alom et al., 2008).

Table 3. Lentil and Mukhikachu equivalent yield, relative yield and land equivalent ratio of different treatments in lentil + Mukhikachu intercropping systems during 2007-08 and 2008-09.

\begin{tabular}{|c|c|c|c|c|c|c|c|c|c|c|}
\hline \multirow{3}{*}{$\begin{array}{l}\text { Treat- } \\
\text { ments }\end{array}$} & \multirow{2}{*}{\multicolumn{2}{|c|}{$\begin{array}{c}\text { Lentil } \\
\text { equivalent } \\
\text { yield (t/ha) }\end{array}$}} & \multirow{2}{*}{\multicolumn{2}{|c|}{$\begin{array}{c}\text { Mukhikachu } \\
\text { equivalent } \\
\text { yield (t/ha) }\end{array}$}} & \multicolumn{4}{|c|}{ Relative yield } & \multirow{2}{*}{\multicolumn{2}{|c|}{$\begin{array}{c}\text { Land } \\
\text { equivalent } \\
\text { ratio (LER) }\end{array}$}} \\
\hline & & & & & \multicolumn{2}{|c|}{ Lentil } & \multicolumn{2}{|c|}{ Mukhikachu } & & \\
\hline & 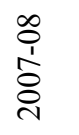 & 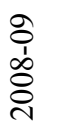 & 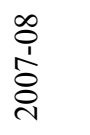 & $\begin{array}{l}\text { oे } \\
1 \\
\infty \\
0 \\
0\end{array}$ & 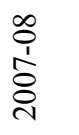 & 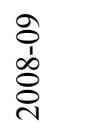 & 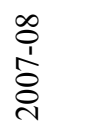 & 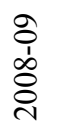 & 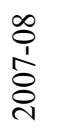 & $\begin{array}{l}\text { oి } \\
1 \\
\infty \\
0 \\
\stackrel{1}{1}\end{array}$ \\
\hline $\mathrm{T}_{1}$ & 1.71 & 1.94 & 7.96 & 9.70 & 1.00 & 1.00 & - & - & 1.00 & 1.00 \\
\hline $\mathrm{T}_{2}$ & 5.04 & 5.72 & 23.40 & 28.60 & - & - & 1.00 & 1.00 & 1.00 & 1.00 \\
\hline $\mathrm{T}_{3}$ & 5.42 & 5.87 & 25.16 & 29.35 & 0.40 & 0.38 & 0.94 & 0.90 & 1.30 & 1.28 \\
\hline $\mathrm{T}_{4}$ & 5.87 & 6.09 & 27.24 & 30.45 & 0.71 & 0.72 & 0.92 & 0.82 & 1.63 & 1.54 \\
\hline $\mathrm{T}_{5}$ & 5.41 & 5.62 & 25.10 & 28.10 & 0.82 & 0.83 & 0.79 & 0.70 & 1.61 & 1.53 \\
\hline $\begin{array}{c}\operatorname{LSD}_{(\mathrm{p}} \\
\leq 0.05)\end{array}$ & 0.83 & 0.85 & 3.84 & 2.75 & - & - & - & - & - & - \\
\hline CV $(\%)$ & 9.36 & 7.10 & 9.37 & 7.83 & - & - & - & - & - & - \\
\hline
\end{tabular}

\section{Price:}

Lentil $=$ Tk.65.00 in 2007-08 and Tk.70.00 per kg in 2008-09

Mukhikachu $=$ Tk.14.00 per kg (in both the years)

\section{Lentil and Mukhikachu relative yield}

Lentil relative yield means yield of intercrop lentil divided by its respective sole crop yield. Lentil relative yield varied greatly from 0.82 to 0.40 in 2007-08 and0.83 to 0.38 in 2008-09 among the intercropping treatments due to different plant population of lentil. It was found that 18 to $60 \%$ in 2007-08 and 17 to $62 \%$ in 2008-09 yield reduction was observed in intercropped system as compared to sole lentil due to plant population (Table 3). Mukhikachu relative yield slightly varied from 0.94 to 0.79 in $2007-08$ and 0.9 to 0.70 in $2008-09$ among the intercropping systems. The yield reduction of Mukhikachu from intercropping system was minimum ( 8 to $21 \%$ in $2007-08$ and 18 to $30 \%$ in $2008-09$ ). Similar findings were also observed by Alom et al. (2008). Minimum yield reduction was observed in treatment $\mathrm{T}_{4}$ where 2 rows of lentil was intercropped in Mukhikachu 
Table 4. Cost benefit analysis of sole crop and intercropping lentil with mukhikachu during 2007-08 and 2008-09.

\begin{tabular}{|c|c|c|c|c|c|c|c|c|c|}
\hline \multirow[b]{2}{*}{ Treatments } & \multicolumn{2}{|c|}{$\begin{array}{l}\text { Gross return } \\
\text { (Tk./ha) }\end{array}$} & \multicolumn{2}{|c|}{$\begin{array}{l}\text { Total cost of } \\
\text { cultivation } \\
(\mathrm{Tk} . / \mathrm{ha})\end{array}$} & \multicolumn{2}{|c|}{$\begin{array}{l}\text { Net return } \\
(\mathrm{Tk} . / \mathrm{ha})\end{array}$} & \multicolumn{3}{|c|}{$\begin{array}{c}\text { Benefit cost ratio } \\
\text { (BCR) }\end{array}$} \\
\hline & 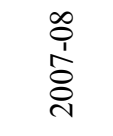 & $\begin{array}{l}\text { ò } \\
1 \\
\infty \\
0 \\
0 \\
1\end{array}$ & 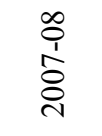 & $\begin{array}{l}\text { ò } \\
1 \\
\infty \\
8 \\
0\end{array}$ & 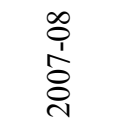 & $\begin{array}{l}\text { oे } \\
1 \\
\infty \\
8 \\
0\end{array}$ & 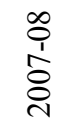 & 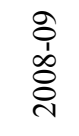 & 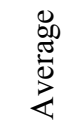 \\
\hline $\mathrm{T}_{1}$ & 111150 & 135800 & 31104 & 36500 & 80046 & 99300 & 3.57 & 3.72 & 3.65 \\
\hline $\mathrm{T}_{2}$ & 327600 & 400400 & 89662 & 92300 & 237938 & 308100 & 3.65 & 4.34 & 4.00 \\
\hline $\mathrm{T}_{3}$ & 352200 & 410900 & 90427 & 93400 & 261773 & 317100 & 3.89 & 4.38 & 4.14 \\
\hline $\mathrm{T}_{4}$ & 381700 & 464100 & 91192 & 95200 & 290508 & 368900 & 4.19 & 4.88 & 4.54 \\
\hline $\mathrm{T}_{5}$ & 351400 & 393400 & 93062 & 97700 & 249938 & 295700 & 3.78 & 4.03 & 3.91 \\
\hline
\end{tabular}

Price:

$$
\begin{aligned}
& \text { Lentil }=\text { Tk.65.00 in 2007-08 and Tk.70.00/kg in 2008-09 } \\
& \text { Mukhikachu }=\text { Tk.14.00/kg (both the years) }
\end{aligned}
$$

\section{Land equivalent ratio (LER)}

The highest LER 1.63 in 2007-08 and 1.54 in 2008-09 was recorded in the treatment of $\mathrm{T}_{4}$ [Mikhikachu (double row) +2 rows of lentil (66\%) between 2 double row of Mukhikachu] and the lowest LER 1.34 in 2007-08 and 1.28 in 2008-09 in the treatment $\mathrm{T}_{3}$ [Mukhikachu (double row) +1 row of lentil $(33 \%)$ between 2 double row of Mukhikachu)] among the intercropping systems (Table 3). LER value of 1.63 in 2007-08 and 1.54 in 2008-09 indicating productivity of intercropping $63 \%$ in $2007-08$ and $54 \%$ in $2008-09$ more land by growing lentil and Mukhikachu in intercropping system. It also expressed that by intercropping lentil with Mukhikachu, a farmer can produce $1.22 \mathrm{t} / \mathrm{ha}$ in 2007-08 and 1.39 t/ha lentil in 2008-09; and 21.60 t/ha in 2007-08 and 23.50 t/ha Mukhikachu in 200809 from one hectare of land instead of growing them separate as sole crop. The results are in agreement with that of Santalla et al. (2001), Basak et al. (2006), Razzaque et al. (2007) and Alom et al. (2008). It is noted that all the intercropping system showed higher LER than sole crop.

\section{Economics}

The gross return (Tk. 381700 in 2007-08 and 464100 per ha in 2008-09) and net return (Tk. 290508 in 2007-08 and 368900 per ha in 2008-09) were found to be maximum in $\mathrm{T}_{4}$ [Mukhikachu (double row) +2 rows of lentil $(66 \%)$ between 2 double rows of Mukhikachu]. Sole lentil gave the lowest gross return and net return (Tk.111150 in 2007-08 and 135800 per ha in 2008-09; and Tk. 80046 in 
2007-08 and Tk.99300 per ha in 2008-09, respectively). Net return was higher under intercropping systems than that of sole cropping systems. The cost of cultivation was the highest under all intercropping systems, particularly in $T_{5}$ [Mikhikachu (double row) + lentil broadcast (100\%)]. This was mainly due to more expenditure in extra labour required for sowing, harvesting, and intercultural operation of two crops. The treatment $\mathrm{T}_{4}$ was more profitable with net return of Tk. 290508 in 2007-08 and 368900 per ha in 2008-09. It might be due to minimum reduction of yield and utilization of different growth resources in intercropping system. Many investigators also reported higher net return in intercropping system than sole crop (Quayyum and Maniruzzaman, 1995; Sarker and Pal, 2004; Basak et al., 2006, Razzaque et al., 2007 and Alom et al., 2008). The maximum benefit cost ratio (BCR) was obtained (4.19 in 2007-08 and 4.88 in 2008-09) in $\mathrm{T}_{4}$ among the intercropping systems. On an average, the highest BCR (4.54) was also recorded in $\mathrm{T}_{4}$ treatment.

Under the above discussion, it could be concluded that Mukhikachu planting in double row system +2 rows of lentil $30 \mathrm{~cm}$ apart $(66 \%)$ between 2 double row of Mukhikachu was the most suitable intercropping combination in terms of lentil equivalent yield (LEY), Mukhikachu equivalent yield (MEY), LER and BCR. So, two rows of lentil $30 \mathrm{~cm}$ apart $(66 \%)$ between 2 double rows of Mukhikachu (20/55/20cm x 45) could be grown as intercropping system for higher productivity and profitability than the sole and other intercropping combinations at south-western part of Bangladesh. Besides, lentil production could be enhanced by intercropping with Mukhikachu.

\section{References}

Alom, M. S., N. K. Paul, and M. A. Quayyum. 2008. Performance of hybrid maize (Zea mays L.) under intercropping systems with mungbean (Vigna radiata L.) in different planting methods. SAARC J. of Agri. 6 (2): 73 - 82.

Bandyopadhyay, S. N. 1984. Nitrogen and water relations in grain sorghum-legume intercropping systems. Ph. D. Dissertation, Indian Agricultural Research Institute, New Delhi.

Basak, N. C., S. M. A., Hossain, I. Islam and N. I. Bhuyan. 2006. Intercroccping wheat with groundnut at variable plant population Bangladesh J. Agril. Res. 31 (2): 207-215.

BRRC (Bangladesh Agricultural Research Council).2005. Fertilizer Recommendation guide. Bangladesh Agril. Res. Coun. Farmgate, New Airport Road, Dhaka-1215.

Islam, M. N., M. M. Haque, and A. Hamid. 2006.Effects of nitrogen and phosphorus fertilizers on nutrient uptake and economic productivity of crops in the maize-bush bean intercropping system. Bangladesh J. Agril. Res. 31 (3): 353-364.

Islam, M. N. and M. Akhteruzzaman, 2008. Survey on multiple cropping systems in farmers field. In: Annual Research Report 2007-08, Agronomy Division. BARI, Joydebpur, Gazipur. pp. 44-48. 
Jukinen, K. 1991. Yield and competition in barley variety mixtures. Agric. Sci. Finl. 63: 278-305.

Kumar, A. and R.P. Singh. 1987. Production potential and economic returns of gram and mustard intercropping systems under rainfed conditions. Indian J. Agron. 32(2): 258-260.

Mead, R. and R. W. Willey. 1980. The concept of a land equivalent ratio and advantages in yields from intercropping. Expt. Agric. 16: 217-228.

Patra, B.C., B.K. Mandal, and A.L. Padhi, 2000. Production potential of winter maize (Zea mays L.) based intercropping systems. Indian J. Agric. Sci. 70(4): 2003-2006.

Quayyum, M.A. and A.F.M. Muniruzzam, 1995. Effect of maize (Zea mays L.) and rice (Oryza sativa) with blackgram (Phaseolus mungo). Indian J. Agron. 40(1): 20-25.

Razzaque, M.A., S. Rafiquzzaman, M.M. Bazzaz, M.A. Ali, and M.M.R. Talukdar. 2007. Study on the intercropping groundnut with chilli at different plant populations. Bangladesh J. Agril. Res. 32(1): 37-43.

Santalla, M., A.P. Rodino, P.A. Casquero, and A.M. De Ron, 2001. Interactions of bush bean intercropped with field and sweet maize. European J. Agron. 15: 185-196.

Sarker, R.K. and P.K. Pal. 2004. Effect of intercropping rice (Oryza sativa) with groundnut (Arachis hypogaea) and pigeonpea (Cajanus cajan) under different row orientations on rainfed uplands. Indian J. Agron. 49 (3): 147-150.

Salam, M.A., M. M.A. Patwary, M.M. Rahman, M.D. Hossain, and M. Saifullah. 2003. Profitability of Mukhikhachu (Collocasia esculenta) production as influenced by different doses and time of application of urea and muriate of potash. Asian J. plant Sci. 2 (2): 233-236. 